\title{
A ALFABETIZAÇÃo SEM CONFINS
}

\author{
LITERACY WITHOUT BORDERS
}

\section{LA ALFABETIZACIÓN SIN FRONTERAS}

Mitsi Pinheiro de Lacerda ${ }^{i}$

\section{RESUMO}

$\mathrm{O}$ artigo indaga sobre algumas condições que configuram a recorrência de uma antiga pergunta nas pautas da educação: “a criança deve ser alfabetizada na educação infantil?”. A pergunta é atribuída à figura de um suposto "perguntador" que sustentaria as seguintes crenças: (i) a alfabetização dispõe de início, meio e fim; (ii) a alfabetização é uma prática sistematizada que cumpre currículos prescritos, é direcionada por métodos e aprimorada por exames e (iii) o alfabetizar difere do brincar. As conversações que tratam da existência desta pergunta são conduzidas em diálogo com diversos autores e com breve observação realizada na educação infantil. $\mathrm{O}$ artigo está dividido em três partes e, a princípio, há o convite por observar com estranhamento a pergunta, de forma a desvelar algumas concepções que a influenciam. A seguir, é inserido um relato de forma a buscar pistas de práticas alfabetizadoras. Por fim, as conclusões refutam a concepção mecanicista de alfabetização.

PALAVRAS-CHAVE: Alfabetização. Educação infantil. Infância.

\section{ABSTRACT}

The essay discusses about some conditions that create the recurrence of an old question in educational agendas, "the child must be literate in kindergarten?". This issue is given to a supposed "questioner" which would support the following beliefs: (i) literacy has a beginning, middle and end; (ii) literacy is a systematic practice and has curriculum, method and evaluation and (iii) the literacy differs from play. The talks about the existence of this question have been conducted in dialogue with several authors and observations on a school kindergarten. The article is divided into three parts which, in principle, there is the invitation to observe the question in order to uncover some views that influence. The following is recorded something of everyday school life in order to seek clues of literacy teachers practice in spacetime. Finally, the conclusions refute the mechanistic conception of literacy.

KEYWORDS: Literacy. Kindergarten. Childhood.

\section{RESUMEN}

El artículo indaga sobre algunas condiciones que configuran la recurrencia de una antigua pregunta en las pautas de la educación: "el niño debe ser alfabetizado en la Educación Infantil?". La pregunta se atribuye a la figura de un supuesto "preguntador" que sostendría las siguientes creencias: (i) la alfabetización dispone de inicio, medio y fin; (ii) la alfabetización es una práctica sistematizada que cumple los currículos prescritos, es dirigida por métodos y mejorada por exámenes y (iii) el alfabetizar difiere del juego. Las conversaciones que tratan de la existencia de esta pregunta son conducidas en diálogo con diversos autores y con breve observación realizada en la Educación Infantil. El artículo está dividido en tres partes y, al principio, hay la invitación por observar con extrañamiento la pregunta, para desvelar algunas concepciones que la influencian. A continuación se inserta un relato para buscar pistas de prácticas alfabetizadoras. Por último, las conclusiones refutan la concepción mecanicista de alfabetización.

PALABRAS CLAVE: Alfabetización. Educación infantil. Infancia

\begin{tabular}{l|c|c|c|c|c|c} 
(C) Rev. Educ. Perspec. & Viçosa, $M G$ & v.8 & n.1 & p.20-35 & jan./abr. 2017 & eISSN 2178-8359 \\
\hline
\end{tabular}




\section{INTRODUÇÃo}

Nunca se sabe de quem são as ideias que a gente mastiga.

J. Joyce

Ela contava que, por volta de 1970, quando lecionava no "Jardim de Infância", costumava comprar lápis de cor e giz de cera para as crianças, pois não havia este material na escola. "Não havia recursos públicos para a compra de material didático?" - eu perguntava; "Não era só isso... não havia lápis porque não era permitido escrever no jardim” - ela respondia. Respondia e contava um segredo: que ela e as outras professoras da escola compravam os instrumentos de escrita e trabalhavam com as crianças, secretamente. Quando alguém chamava ao portão da escola e uma delas vislumbrava a presença da inspetora escolar, corriam a esconder o material de escrita e a distribuir massinha de modelar para as crianças. Ah, estas professoras... eram "praticantes do cotidiano" (CERTEAU, 1994).

Esta talvez seja a primeira narrativa que eu tenha ouvido sobre práticas alfabetizadoras na Educação Infantil, pois que era contada por minha mãe, professora, quando eu ainda era criança. Minha mãe contava e sorria; penso que ela gostava da façanha de ensinar as letras às escondidas, que ela gostava da cumplicidade entre as professoras que corriam a esconder o material de escrita na eminência do "perigo", que gostava de se arriscar por aquilo em que acreditava. Ah, estas professoras atrevidas...

Este artigo tem por objetivo tratar de uma antiga questão que, renitentemente, é recorrente nas pautas da educação: “a criança deve ser alfabetizada na Educação Infantil?". Esta é a pergunta desde a qual o texto foi tecido, mas, note que este não é o objetivo do artigo, afinal, bastaria responder com um definitivo "não". A intenção do artigo se refere, portanto, a indagar a respeito do retorno a esta pergunta, compreendendo-a enquanto material desde o qual é desenvolvida uma discussão, cuja natureza é não ter fim. É sabido que a escrita de um artigo que se origina a partir de uma pergunta, deveria, tradicionalmente, conduzir a uma resposta; porém, de forma a evitar frustrações, antecipo que o desenvolvimento do artigo não se propõe a responder a esta pergunta, mas a indagar sobre alguns motivos que levam à sua existência. Não será encontrado neste texto, portanto, a defesa da autora em relação a seu posicionamento, mas conversações com a emergência desta pergunta - estas sim, objetivo do artigo.

$\mathrm{O}$ artigo está dividido em três partes. A princípio, convido a observar com estranhamento a pergunta, de forma a desvelar algumas concepções que a influenciam. A seguir, trago o breve registro do cotidiano de uma escola de Educação Infantil, de forma a buscar pistas de práticas alfabetizadoras neste espaçotempo. Por fim, concluo o estudo convidando a que se

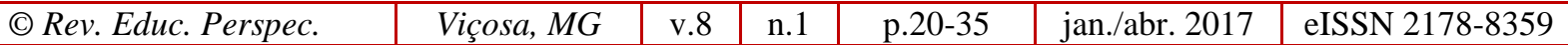


compreenda a alfabetização a partir de orientações freirianas, sobretudo, em sua incomensurabilidade e como prática política e libertadora.

\section{A ALFABETIZAÇÃo CIRCUNSCRITA EM ESPAÇOS, TEMPOS, CURRíCULOS, MÉTODOS E EXAMES}

Em texto bastante provocativo e que espantosamente nos leva a entender quão pouco vemos, Heinz von Foerster (1996) narra algumas histórias. Dentre elas, há o relato acerca do encontro entre Castañeda e um bruxo que deveria lhe ensinar a ver. Caminhando ambos pela selva, o bruxo renitentemente apontava algo e dizia: "Olha!" - mas o pobre Castañeda nada via. Não via nada, o coitado. A caminhada prosseguiu até que, em determinado momento, o bruxo disse: "Agora entendo qual é teu problema! [...] Tu não podes ver o que não podes explicar. Trata de esquecer de tuas explicações e começarás a ver" (FOERSTER, 1996, p. 67).

Pois bem, façamos uma reescrita desta história para pensarmos naquilo que nos interessa. Nesta versão criada a partir da história de von Foerster, encontramos Fulana que caminhava com Beltrana por uma classe de Educação Infantil, quando Fulana perguntou se aquelas crianças deveriam ser alfabetizadas. De forma a provocar Fulana a pensar sobre sua pergunta, Beltrana dizia: "Olha!" - mas Fulana somente via um currículo, um exame e um método. Continuaram caminhando até que Beltrana pensou, e disse: “Agora entendo o teu problema! Tu perguntas se podes alfabetizar estas crianças porque pensas que a alfabetização é restrita à sistematização de certos procedimentos. Trata de esquecer estes aprisionamentos e começarás a ver a alfabetização por toda a parte, o tempo todo".

A sabedoria do bruxo ajuda a deslocar o foco de algo que foi circunscrito, para a tessitura que o atravessa. A pergunta acerca da alfabetização na Educação Infantil, que facilmente se desdobra em um grande número de respostas, mantém ocultas as fibras que a tecem. As respostas, em grande parte, podem ser resumidas em "sim" ou "não", e se considerarmos que uma resposta é uma explicação, aprenderemos com o bruxo que temos explicado muito e visto pouco. Certamente, neste texto não me presto a querer ver "mais", mas apenas a afirmar que temos visto pouco, e eu aí inclusa e resignada, pois míope que sou, sempre achei mais fácil ver para dentro, do que para fora.

“A criança deve ser alfabetizada na Educação Infantil?" - é uma pergunta que não costuma provocar estranhamento, pois que é uma pergunta aberta a uma resposta. Perguntas que facilmente aceitam respostas são uma grande armadilha, pois cobrem com sua simplicidade toda a complexa rede que as alimentam e sustentam. Nesta seção, portanto, pretendo discutir

n.1 1 p.20-35


o quão estranha é esta pergunta e tentar fazer com ela deixe de se mostrar tão simples, tão receptiva a um "sim" ou "não".

Nesta pergunta residem provocações. Quando ela é feita, junto a ela são tecidas proposições que não se mostram, que são ocultas, mas que se articulam às concepções e crenças que se tem sobre a infância, sobre a escola, sobre a alfabetização, sobre a leitura e escrita, sobre as temporalidades e espacialidades. Uma pergunta provém de um perguntador que acredita em algo, e é este "algo" que faz emergir a pergunta. Na pergunta sobre se devemos ou não alfabetizar na Educação Infantil, o perguntador inscreve aquilo em que acredita, e aqui pretendo, atrevidamente, sugerir a existência de algumas destas crenças. Sem nenhuma intenção de esgotar o rol de crenças, vamos a uma delas: "A alfabetização dispõe de início, meio e fim".

Quando indago sobre a ocorrência de algo, junto a isso sou levada a acreditar que esta ocorrência tem um início temporal e uma localização espacial. Parece óbvio, simples, mas não é. É fato que algumas práticas cotidianas têm início, meio e fim: assar um bolo, fazer um passeio na praça, plantar uma árvore. Ou não. Ou... certamente, não. Se olharmos cuidadosamente para o bolo, veremos que sua receita é fruto de tentativas, conversas, conselhos e tantas outras reminiscências que atravessam espaços e tempos até chegarem às suas mãos, e que o que envolve este bolo não se finda ao ser assado, pois que será assado, saboreado, adentrará outras conversas com seu sabor, fará emergir aquelas outras conversas, passadas... um bolo sem começo, nem fim. Há práticas que são observadas desde um lugar específico, mas que se desdobram anterior e posteriormente, espalhando indícios de suas condições de possibilidade, de sua existência, de seu devir.

$\mathrm{Na}$ atualidade, encontra-se estabelecido que até a idade máxima de 8 anos, todas as crianças devam estar alfabetizadas ${ }^{\mathrm{ii}}$ - arquitetura que configura um período, no interior do qual, a professora alfabetizadora e suas crianças devem se posicionar. Tão estranho quanto o início, é o fim: fala-se em "alfabetização como processo", e o circunscrevem a partir da cronologia infantil, como se esta coincidisse com supostos universais de desenvolvimento. O que está posto, é: aprender até os 8 anos. Depois disso, a pergunta perturbadora desaparece. Ninguém, nunca mais, em tempo algum ${ }^{\text {iii }}$, pergunta: a criança que ainda não sabe ler e escrever, deve ser alfabetizada no quinto ano de escolaridade? O adolescente, que também ainda não sabe, deve ser alfabetizado no oitavo ano? Não, estas perguntas não existem, pois, o problema real, - a alfabetização de todos (as) - aparentemente, é o que menos importa. O que temos de real é sua delimitação no interior de um período sobre o qual o poder público se responsabiliza parcialmente, para, findo este período, abandonar a questão. 
Insisto em que o problema da alfabetização não é o que importa em alfabetização, posto que ele deixa de existir tão logo avancemos a busca por ele nos níveis de escolarização: antes, a alfabetização é proibida; depois, é esquecida. A preocupação com a alfabetização somente é colocada para professoras que trabalham com turmas de 6,7 e 8 anos, mas, extraordinariamente, deixa de existir para as professoras que trabalham com crianças a partir de 9 anos, ou impedida para as que atuam em Educação Infantil. Há, portanto, um período de "proibição" para se alfabetizar - a Educação Infantil, e um interstício referente a crianças na faixa etária aproximadamente compreendida entre 9 e 14 anos, durante o qual a alfabetização é espantosa e temporariamente suspensa.

A pergunta - "a criança deve ser alfabetizada na Educação Infantil?" - não é, portanto, uma pergunta estranha? E esta outra: "e o garoto que estuda no quinto ano, deve ser inserido em práticas alfabetizadoras?”. Quando afirmo que o perguntador acredita que a alfabetização é passível de ter um início, preciso registrar, também, que o perguntador não se interessa por saber o que acontece depois - depois que tudo isso se passa, depois que o início começa aos 6 anos, e depois que ele acaba aos 8. O perguntador, talvez conduzido por concepções compensatórias ou incentivado por lógicas advindas do mercado, quer saber se é possível antecipar isso, se é possível começar um pouco "antes", na Educação Infantil, mas o perguntador não quer saber sobre o que acontece nesse "depois" em que ele tacitamente acredita. Ele quer saber se pode começar "antes", de forma a transpor, para esta modalidade de ensino, todo o aparato metodológico, curricular e mensurativo que configura aquilo que entende por alfabetização. Isso nos leva, então, a outra possível crença do perguntador: "A alfabetização é uma prática sistematizada que cumpre currículos prescritos, é direcionada por métodos e aprimorada por exames".

Mergulhemos com estranhamento também aqui: quando o perguntador pergunta se "a criança deve ser alfabetizada na Educação Infantil", ele está pensando na parte operacional da coisa. O que deve ser ensinado? Como deve ser ensinado? Como deve ser examinado? Ele está pensando como pensavam aquelas senhoras das quais minha mãe fugia há quase 50 anos, de que há procedimentos e instrumentos próprios à alfabetização. Simplificando enormemente a questão, seria algo assim: se a Educação Infantil alfabetiza, então vamos dar lápis e papel às crianças, vamos colar alfabetos pela sala, vamos examinar e conceitualizar as escritas. Se a Educação Infantil não alfabetiza, então vamos cantar as musiquinhas ${ }^{\text {iv }}$, amassar a massinha, ouvir a historinha, brincar ${ }^{\mathrm{v}}$.

Tudo isso é compreensível, já que fomos ensinados a didatizar muito e a politizar pouco a educação. Quando o perguntador pensa na alfabetização em uma classe de Educação Infantil, provavelmente constrói uma imagem no interior da qual crianças escrevem em seus cadernos tarefas propostas pela professora, enquanto os brinquedos e os livros de histórias

\begin{tabular}{l|l|l|l|l|l|l} 
(c) Rev. Educ. Perspec. & Viçosa, $M G$ & v.8 & n.1 & p.20-35 & jan./abr. 2017 & eISSN 2178-8359 \\
\hline
\end{tabular}


permanecem inertes nos armários. A alfabetização é passível de muitas "entradas" currículos, métodos, exames - e todo este aparato didático é impensável em uma classe de Educação Infantil. Aqui se encontra a armadilha: a alfabetização quase não é vista, encoberta por toda esta parafernália didática. Libertemo-la, vejamos o que é a alfabetização sem conteúdos, sem métodos e sem exames para que assim, desnuda, ela possa se expandir por toda a educação e por toda a sociedade.

Por fim, dadas as restrições dimensionais do artigo, trago apenas mais uma possibilidade (a última) a ser acrescida ao rol de crenças do nosso ingênuo perguntador: "O alfabetizar difere do brincar". Quando se fala em alfabetização na Educação Infantil, geralmente é aventado o receio pela perda da ludicidade, a qual deveria ser própria desta fase escolar ${ }^{\mathrm{vi}}$. Esta perda ocorre quando a prática alfabetizadora é associada ao exercício de dinâmicas mecanicistas e desprovidas de sentido, e quando a palavra escrita é desprovida de seu contexto e entregue a reduções, combinações, repetições. Diferente disso, alfabetização e ludicidade são indissociáveis, uma vez que a leitura e a escrita são inseparáveis da imersão do sujeito em processos criativos e atravessados pela fantasia.

O recorte entre alfabetização e ludicidade, portanto, não faz sentido quando se entende que a Educação Infantil também é um espaço possível a inúmeras práticas que envolvam a criança no imensurável universo da leitura e escrita. A aceitação desta afirmação, contudo, requer a compreensão de que o alfabetizar não guarda qualquer compromisso com propostas de sistematização. Práticas alfabetizadoras transitam nas rodas de conversas, na corporeidade vivenciada, no olhar curioso sobre o mundo, no trânsito aparentemente caótico a partir do qual as crianças se percebem e se organizam e em tantas outras invenções cotidianas. É ali, no interior da linguagem, nos deslocamentos, naquilo que nos atravessa enquanto experiência escolar, que vivenciamos práticas alfabetizadoras. E tudo isso - insisto - não guarda qualquer relação com a versão mecanicista que tem retratado a alfabetização e a reduzido à consecução de objetivos e aquisição de habilidades/competências. Afirmar que não se alfabetiza na Educação Infantil, induz à renúncia por se pensar em alfabetização, sempre. Há décadas que Paulo Freire, Emília Ferreiro e tantos outros estudiosos brasileiros ${ }^{\text {vii }}$ nos falam sobre a alfabetização que acontece independente de processos de escolarização, por isso causa espanto notar que, atualmente, ainda se dicotomize o brincar e o alfabetizar.

É preciso pensar sobre como as orientações que circunscrevem "o brincar" na Educação Infantil e no Ensino Fundamental, se materializam nas escolas. Esta divisão dificulta o entendimento de que a ludicidade é algo inerente ao sujeito, e que, junto a ele, percorre toda a sua história - assim como dificulta aprender a lição freiriana tão mencionada em educação, a de que lemos o mundo antes mesmo de ler a palavra. Por isso, restringir a Educação Infantil ao lúdico implica em um direcionamento inútil, afinal, como tenho sempre afirmado, a

\begin{tabular}{l|c|c|c|c|c|c} 
(C) Rev. Educ. Perspec. & Viçosa, $M G$ & v.8 & n.1 & p.20-35 & jan./abr. 2017 & eISSN 2178-8359 \\
\hline
\end{tabular}


ludicidade do outro não depende de você. Ninguém determina que o outro vivencie sua ludicidade apenas porque foi incluso junto a atividades recreativas ou teve acesso a instrumentos lúdicos. Uma criança pode brincar com um barbante, e se entediar com o brinquedo mais sofisticado. Esta crença pela perda da ludicidade ao se trabalhar com alfabetização, inscreve fronteiras entre o que deveria ser a ludicidade e a prática alfabetizadora, mecanizando o lúdico ao tomá-lo enquanto dispositivo a ser acionado externamente, e também mecanizando a alfabetização, reduzindo-a a atividades específicas.

Sabemos que axiomas são princípios evidentes em si mesmos, são afirmações óbvias, aceitas sem discussão. Axiomas alimentam crenças, e crenças configuram mundos - e nesses mundos habitam práticas. Nosso perguntador dispõe de crenças que fazem emergir sua pergunta, e por isso ele quer saber se é próprio que se alfabetize na Educação Infantil. Em sua pergunta habitam modelos específicos de alfabetização, de espaço, de tempo, de currículo, de exame, de criança, de ludicidade. O perguntador acredita e afirma os modelos que emprega em seu perguntar, por isso ele pergunta. Abandonemo-lo, pois.

\section{A INCOMENSURABILIDADE DA ALFABETIZAÇÃ̃o}

Abandonado o perguntador e seus axiomas, adentrei uma escola pública de Educação Infantil de forma a buscar práticas de leitura e escrita, indissociáveis de práticas lúdicas. Esta busca foi orientada pela compreensão de que a alfabetização é um processo vivenciado ao longo de toda a vida, e que, na instituição, seriam encontradas conexões de vivências alfabetizadoras, que são trançadas em redes nas vidas de todos nós.

A escola visitada é anexa à praça principal de uma cidade pequena - é uma praça com uma escola dentro. Sua estrutura, com grandes colunas, lembra os antigos coretos, sendo que nas laterais, não há paredes de alvenaria ou janelas, em uma configuração panóptica que se desloca segundo os movimentos do observador. A escola é parte da praça e aberta à rua, mas, esta ligação física é aparentemente negada pela presença simbólica de fronteiras. No interior da escola há uma única sala de aula, um espaço compartilhado por quatro turmas de Educação Infantil. Nesta sala de aula, a falta de alvenaria favorece a observação, circulação e interação, e, ao mesmo tempo, possibilita a inserção de limites invisíveis e tacitamente compartilhados por todos. A inexistência de paredes que dividiriam as classes, nesta escola, é a condição de possibilidade para a existência de paredes invisíveis.

No Brasil, as instituições destinadas ao atendimento de crianças de zero a seis anos surgiram no Império, e seu objetivo era o amparo de crianças abandonadas. Em 1870, chega ao Brasil a concepção de "Jardim de Infância", uma instituição idealizada pelo médico alemão Froebel,

\begin{tabular}{l|c|c|c|c|c|c} 
(C) Rev. Educ. Perspec. & Viçosa, $M G$ & v.8 & n.1 & p.20-35 & jan./abr. 2017 & eISSN 2178-8359 \\
\hline
\end{tabular}


cujo princípio norteador era a criação de "viveiros infantis" no interior dos quais, as crianças seriam "plantinhas" a serem cultivadas. O zelo e o bom cuidado, portanto, fariam as "sementes germinarem" e a sociedade "colheria bons frutos". No início do século XX, os jardins de infância já eram uma realidade no Brasil. Muitos manuais de orientação foram criados de forma a detalhar o perfil psicológico da criança nesta fase etária, a metodologia de trabalho no Jardim, o modelo adequado para a edificação da instituição, distribuição do mobiliário e equipamentos, sugestões de atividades e organização do espaço e tempo escolar. Em Wills e Stegeman $(1967)^{\text {viii }}$, é possível encontrar orientações para a criação e desenvolvimento de um "Jardim de Infância". Os autores, americanos, oferecem todo o detalhamento necessário à organização do lugar, e à prática docente:

\begin{abstract}
Um menino ou um adulto que não recebem uma quantidade razoável de elogios e atenção por se comportarem de maneira conveniente, sentirão prazer nas atenções negativas que resultam de um procedimento mau. [...] Lugar às mesas - Se algumas crianças tomam o leite servido pela escola e outras trazem a sua merenda de casa, é melhor chamar primeiro as que compram o leite e fazê-las sentar tôdas de uma vez e só chamar as outras para ocuparem as cadeiras quando as primeiras já estiverem acomodadas. [...] Algumas crianças se masturbam ou chupam os dedos no período de repouso. Tais sintomas são devidos a muitas causas. A masturbação, por exemplo, pode ser causada por roupa apertada. [...] Durante tôdas as atividades do Jardim, a professôra não deve esquecer a boa posição das crianças. Estas, ao se sentarem precisam manter as costas eretas e ter os pés firmes no chão. [...] Como ensinar as crianças a saltitar - [...] mandar as crianças ficarem de pé, num pé só; depois pular com êsse pé; pisar com o outro pé, pular com êsse pé [...]. (WILLS; STEGEMAN, 1967, p. 181)
\end{abstract}

$\mathrm{Na}$ atualidade, embora algumas orientações de naturezas behaviorista e preconceituosa tenham sido quase completamente extintas - em função de novos debates sobre infâncias, sociedades, sexualidades, desenvolvimentos e aprendizagens - a rotina e organização do espaçotempo, inclusas no cotidiano dos jardins de infância, se mantêm em parte. Durante o trabalho de campo, foi possível observar que há uma rotina cumprida pela escola, e que esta rotina é proveniente das orientações iniciais postas à constituição dos primeiros jardins da infância.

As crianças chegam, sentam-se junto às mesinhas e recebem o primeiro lanche e depois são chamadas a sentarem-se na "rodinha" para a primeira atividade do dia: as cantigas. As professoras reúnem todas as crianças e começam a cantar, e também a rezar. Concluída esta atividade, as crianças retornam a seus lugares, sem que haja necessidade de ordenação nesse sentido. Aparentemente, elas já incorporaram a rotina da escola, e sabem exatamente o que devem fazer. As professoras se dirigem a seus armários, consultam o cronograma semanal e, aos poucos, cada turma se organiza para dar início à segunda atividade do dia.

n.1 1 p.20-35


O espaço único compartilhado pelas quatro turmas é, então, reservado apenas a duas delas neste momento. A princípio, todas as crianças (aproximadamente 80) estiveram reunidas na "rodinha", mas, a seguir, cada turma se dirigiu ao local especificado para aquele dia e horário. É perceptível que todas as crianças sabem exatamente o que devem fazer. Elas se levantam da rodinha, aguardam que a professora diga o local em que irão trabalhar, e para lá se dirigem. Não há barulho, correrias, gritos. Tudo é extremamente tranquilo, diferentemente de escolas em que cada turma ocupa um local específico: sua sala de aula. A inexistência de alvenaria para dividir as turmas, de certa forma, contribui para esta atmosfera. Como todos podem observar a todos continuamente, não há necessidade de muitos deslocamentos, nem as "fugas" para ir ao encontro do que se passa "lá fora".

Meu interesse ficou centrado nos fluxos das crianças e professoras. Havia nos movimentos uma harmonia e serenidade dificilmente encontradas quando nos deparamos com um número expressivo de crianças. A sensação é de que não havia a urgência por realizar as atividades propostas. Junto a isso, aparentemente não havia a necessidade por conversar, interagir, inventar. Não foi possível notar a ocorrência destas práticas, pois a escola é engenhosamente organizada e cada um sabe exatamente o que deve fazer. $O$ fato de não estarem circunscritos por paredes de alvenaria influenciava as relações entre todos, pois, se não estavam "presos", não necessitavam da fuga. Sua liberdade era suficiente para aprisioná-los. A ampla visibilidade oferecida a todos tecia a calmaria, uma vez que nenhum deslocamento era necessário para a visualização do que se passava. Como as mesinhas de trabalho eram organizadas em blocos e unidas, também não havia necessidade de deslocamentos para conversas. As crianças permaneciam sentadas, entregues às atividades propostas e, em grande parte, caladas.

A quase inexistência de conversas era perturbadora. Nenhuma ordenação verbal era emitida com este propósito, mas a configuração do lugar e a ordenação do tempo, de certa forma, prestavam este serviço. A inexistência de conversas limita a existência da linguagem, embora não a anule - e práticas nas quais a linguagem é reduzida, afetam negativamente a ambiência alfabetizadora, posto que os universos que se expandem nas teias discursivas configuram situações ótimas ao exercício intelectual inerente à leitura e escrita.

No jardim de infância visitado, as crianças não precisavam criar táticas (CERTEAU, 1994) para burlar o que seria imposto pelo forte ${ }^{\mathrm{ix}}$, uma vez que seus agrupamentos são livres, a visibilidade é total e não há regulações explícitas aos acessos. Há serenidade, pois as crianças sabem que suas necessidades fisiológicas não prescindem da autorização da professora, e que seus amigos e suas "tias" estão sempre ali, ao alcance do olhar. Não eram reguladas pelos limites da alvenaria, que as poderia dispor em agitação; eram reguladas pela visibilidade, que amenizava seus fluxos corporais e verbais.

\begin{tabular}{l|l|l|l|l|l|l} 
(C) Rev. Educ. Perspec. & Viçosa, $M G$ & v.8 & n.1 & p.20-35 & jan./abr. 2017 & eISSN 2178-8359 \\
\hline
\end{tabular}


Após a "rodinha" e as canções, uma das professoras conduziu sua turma até o parquinho de areia e as crianças brincaram livremente. Há baldes e pás para as brincadeiras, e as crianças demonstraram bastante familiaridade com a atividade. As crianças eram observadas pela professora e uma funcionária durante todo o tempo; elas se mantiveram à distância, sem interferir. Entre as crianças, poucos diálogos que pudessem ser captados por ouvidos adultos, mas muitas conversações no interior da linguagem infantil.

Haveria algum trabalho voltado à alfabetização naquela atividade no parquinho? Bom, se tomarmos a ideia de alfabetização orientados (as) por um pensamento positivista, a resposta seria "não". Mas se aprendermos com Maturana (2001), que o alimento para o conhecer nem sempre dispõe de visibilidade, saberemos que a cooperação, a emoção, a amizade e, muito especialmente, as linguagens, são imprescindíveis durante o desenvolvimento e a aprendizagem. Brincando ali, as crianças aprendem coisas importantíssimas referentes à alfabetização, tais como a cooperação, a auto-organização e a autoria de si. Parece rotina, parece. Mas, assim como a observação de minúsculos grãos de areia revela uma infinidade de diferenciações, também a rotina precisa ser vista assim, devagar, com cuidado, mais de perto.

A seguir, voltei para a sala de aula e encontrei outra professora com seus alunos. Ela estava trabalhando com números e os mostrava escritos em cartazes, perguntando às crianças quais numerais eram aqueles. Todas as crianças respondiam prontamente. Mostrava o 5, as crianças diziam "cinco". Mostrava o 8, as crianças diziam "oito". Já sabiam os nomes dos números, assim como também já sabiam que deveriam cumprir o que estava posto no cronograma. $\mathrm{O}$ jardim não assumia explicitamente uma função alfabetizadora, mas se dedicava a perpetuar lições de escola. Enquanto esta atividade se desenrolava no jardim de infância, tenho a impressão de ter visto Vigotski (2009) passeando pelo jardim da cidade, quem sabe pensando nas belas lições que tentou nos ensinar sobre o que há de potencial no desenvolvimento e na aprendizagem.

Dali, dirigi-me à sala de leitura. Sentada diante de uma mesinha de jogos, uma menina me mostrou a letra "A" e disse: "é a minha letra". Aparentemente, cada criança brincava isoladamente com as peças, mas, assim que a menina mostrou a peça com a letra, as outras crianças passaram a buscar peças com letras e a mostrar as letras dos seus nomes e dos nomes de familiares. Aquela atividade não era especificamente "direcionada" para a alfabetização, e nem havia mediação da professora nesse sentido. Porém, a criança cujo nome começa com "A" deu início a um movimento que se estendeu aos demais integrantes da mesa. Era como se ela dissesse: "estou na escola, e escola é lugar de ler e escrever". Este evento sinaliza que as crianças, independentemente da idade ou modalidade de ensino na qual estão inseridas, pensam sobre a leitura e a escrita e conhecem a lógica escolar. As crianças nascem em um mundo letrado, e as atividades de observar e manipular materiais de leitura e instrumentos de

\begin{tabular}{l|c|c|c|c|c|c|} 
(C) Rev. Educ. Perspec. & Viçosa, $M G$ & v.8 & n.1 & p.20-35 & jan./abr. 2017 & eISSN 2178-8359 \\
\hline
\end{tabular}


escrita estão presentes desde muito cedo em suas vidas. Junto a isso, tacitamente sabem que a aprendizagem da leitura e da escrita foi institucionalmente aprisionada na escola, assim como também dispõem de conhecimentos sobre a apresentação de sua sequência didática: letras, sílabas, frases... acho que era isso o que aquelas crianças queriam me mostrar. Queriam me mostrar que conheciam a lógica escolar, posto que esta era a expectativa que depositavam em $\operatorname{mim}$.

Aquela sala dispunha de farto material escrito, o qual era utilizado para manipulação, e rapidamente abandonado. Talvez, pressionada pela existência da pergunta "a criança deve ser alfabetizada na Educação Infantil?", a professora da Educação Infantil não assumia a postura de professora alfabetizadora, mas também não refutava o movimento que ocorria em sua sala de aula. Ela não intervia e não negava, e muito assombradamente, eu compreendi o que viria a ser uma prática neutra. As crianças mostravam e discutiam as letras que eram suas e as letras que eram de fulanos e beltranos, e a professora se mantinha ausente do debate. Talvez, ao participar dos movimentos promovidos pelas crianças, a professora precisasse se posicionar em relação a dois modos distintos de se pensar a alfabetização: um deles, hegemônico, trata a alfabetização enquanto período dedicado à sistematização do ensino da língua; o outro, político, a compreende enquanto processo que ocorre durante toda a vida dos sujeitos.

“A criança deve ser alfabetizada na Educação Infantil?" - era a pergunta que renitentemente aguardava uma resposta e uma postura da professora. Ferreiro (1995) discute a questão sobre a pertinência do trabalho com alfabetização na Educação Infantil também questionando esta pergunta, uma vez que, segundo ela, é preciso observar os pressupostos nos quais ela se baseia. Se a perspectiva é de que as crianças somente começam a aprender quando a escola passa a lhes ensinar, então o entendimento é de que a criança aprende a ler ao ingressar no Ensino Fundamental, quando as práticas didáticas são voltadas especificamente para esse fim: cópias, ditados, exercícios de prontidão e memorização. Se, ao contrário, há concordância sobre o ensino da leitura e da escrita na Educação Infantil, também estas classes adotam o formato pedagógico do Ensino Fundamental, antecipando as mesmas práticas mecanicistas e configurando uma pré-escola preparatória para a escola.

Pensar sobre alfabetização na Educação Infantil não implica na reprodução de práticas didáticas do Ensino Fundamental, nem na "preparação" das crianças para o ingresso nesta etapa, nem no compromisso por alcançar a proficiência de todas elas ao findar do ano. A alfabetização na Educação Infantil deve fazer parte do desenvolvimento e aprendizagem de crianças que estão imersas na vida onde a palavra é escrita e lida continuamente. Não se trata de investir no "ensino" da leitura e da escrita, mas em permitir que estas práticas presentes na

n.1 p.20-35


vida, também estejam presentes na escola, sem que sua entrada seja didatizada e muito menos examinada:

A pré-escola precisa ser um espaço onde a criança tenha contato com a leitura e a escrita. Onde possa pensar sobre o que representa e de que modo se comunica através da escrita. Onde a leitura e a escrita possam ser utilizadas com sentido. (SAMPAIO, 1997, p. 61)

No momento da merenda, a funcionária da cantina serviu a refeição às crianças. Por toda a escola, embalagens de produtos industrializados, cartazes, livros e outros portadores de textos se encontravam à vista. Neste dia na escola, não presenciei as professoras fazerem uso destes materiais em uma prática intencional voltada à alfabetização, assim como não observei a exploração dos infinitos de linguagens e corporeidades com este propósito. Penso que a alfabetização, na Educação Infantil, foi deixada no limbo: receosas por configurarem práticas assumidamente alfabetizadoras na Educação Infantil, algumas professoras negligenciam explorar a linguagem escrita. Esta postura aprofunda ainda mais o fosso entre Educação Infantil e Ensino Fundamental, reforçando "o brincar e o preparar" aqui, e "o aprender e o sistematizar" acolá. Esta dura distinção dificulta a compreensão de que a ludicidade e a aprendizagem se mesclam harmoniosamente, e de que a preparação e a sistematização são aparatos mecânicos que precisamos continuamente questionar e refutar.

A escassa existência de posturas alfabetizadoras postas institucionalmente, contudo, não impede a existência de vivências alfabetizadoras instituintes na Educação Infantil. Brincando, conversando e movendo-se, as crianças ensinam e aprendem sobre este universo imensurável da leitura e da escrita, tecendo sentidos, posicionando-se politicamente no mundo, inscrevendo-se em sociedades, observando, pensando. Enquanto a escola define o espaço e tempo para que a alfabetização ocorra, as crianças a desdobram em si e no mundo, infinitamente.

\section{CONCLUSÃO}

A ida à escola intensificou meu interesse por conhecer a alfabetização na Educação Infantil, modalidade de ensino que não está sujeita à regulação do Ensino Fundamental. No Ensino Fundamental, a alfabetização se encontra regulada por várias "entradas". Há um currículo a ser cumprido, há exames internos e externos, há uma espacialidade e uma temporalidade. Há também a terminalidade, e talvez daí seu caráter de urgência, desde que o plano institucional estipulou a alfabetização até os 8 anos de idade. Todas estas regulações no Ensino Fundamental têm contribuído para o retorno da centralidade do método na alfabetização, e foi

n.1 p.20-35


justamente isso que me conduziu até a Educação Infantil e ao encontro de crianças e professoras que deveriam estar libertas de todas estas orientações e interferências.

Há quase duas décadas, Sampaio (1997) denunciava uma concepção de pré-escola que prepara para a escola. Em diálogo com as ideias vigotskianas, afirmava que esta concepção dispõe como pressuposto que o desenvolvimento conduz à aprendizagem, quando, conforme aprendemos com o teórico bielorrusso, desenvolvimento e aprendizagem são recorrentes. Sampaio afirmava que a concepção segundo a qual a pré-escola seria a responsável pela preparação para a escola, inscreveria práticas mecanicistas, behavioristas e positivistas. Isto subtrai da pré-escola sua participação na tessitura alfabetizadora, reduzindo-a enquanto modalidade de ensino posta a serviço da escola, assim como reduzindo, também, a própria noção de alfabetização. Para a autora,

\begin{abstract}
Uma escola que opte por favorecer a apropriação da linguagem escrita prioriza situações de interação em que a escrita seja utilizada na plenitude de suas funções sociais. Porém, a escola que prioriza a língua escrita vinculada estritamente ao sistema de normas se divorcia da linguagem, esvaziando-a de sentido (SAMPAIO, 1997, p. 56).
\end{abstract}

A pré-escola que toma a linguagem como centro de sua proposta alfabetizadora, conduz seu trabalho em meio à tessitura infinita das linguagens em uso na sociedade, sem fazer qualquer recorte espaçotemporal ou submetê-la à normatização. Diferente disso, a pré-escola que prioriza o ensino da língua durante a alfabetização, como vimos acima com Sampaio, se dedica à transmissão de seus aspectos técnicos de forma a preparar as crianças para a sobreposição de novos aspectos técnicos ao ingressarem na "escola". No interior desta préescola reduzida à lógica preparatória, a autora sinaliza a formação positivista das professoras e a persistência de um perfil docente pautado na transmissão, dizendo que "A preocupação é com a melhor forma de ensinar e não com o sentido que possa ter para as crianças o que está sendo ensinado. Esquece-se, a professora, de que ninguém aprende o que não lhe faz sentido" (SAMPAIO, 1997, p. 57, grifo da autora).

A pergunta que indaga sobre a pertinência da alfabetização em classes de Educação Infantil contém, em si, uma concepção mecanicista de aprendizagem e uma concepção que toma o ensino enquanto repasse. Esta é uma pergunta velha, alimentada por concepções que remontam, pelo menos, a quatrocentos anos de pensamento moderno, cuja herança ainda nos atravessa com suas ideias de ordenação, classificação, causalidade e tantos outros fluídos que mecanizam o pensamento (LACERDA, 2015). Diferente de oferecer uma resposta à pergunta: "devemos alfabetizar na Educação Infantil?" - é preciso indagar acerca dos pressupostos que fazem emergir esta pergunta. Já alertei anteriormente sobre os "perigos" da pergunta. Há uma tendência a que uma pergunta circunscreva um objeto, um sujeito, uma

\begin{tabular}{l|c|c|c|c|c|c|} 
(C) Rev. Educ. Perspec. & Viçosa, $M G$ & v.8 & n.1 & p.20-35 & jan./abr. 2017 & eISSN 2178-8359 \\
\hline
\end{tabular}


emoção, uma prática; é preciso observar, epistemologicamente, se nosso ato de perguntar não se presta a tornar ainda mais arraigada a herança conceitual que temos recebido e transmitido no decorrer dos séculos.

Ao encerrar esta escrita, estou ciente de que ela é velha. A pergunta inicial, a rotina observada no "Jardim de Infância", os manuais instrucionais que foram citados, as alusões ao texto teórico - quase tudo remonta há várias décadas. A persistência de tudo isso na atualidade, contudo, possibilitou a escrita deste texto, alimentado pelo estranhamento.

Há tempos nosso querido Paulo Freire tem ensinado sobre a presença das leituras e das escritas na vida, desde sempre e para sempre, e em grande parte desprovidas de caracteres gráficos, e profundamente encarnadas no mundo. Um instante antes da célebre frase que ilustra uma enormidade de cartazes pendurados pelas paredes das escolas ${ }^{\mathrm{x}}$, ele diz da "compreensão crítica do ato de ler, que não se esgota na decodificação pura da palavra escrita e ou da linguagem escrita, mas que se antecipa e se alonga na inteligência do mundo" (FREIRE, 1997, p. 11), e isso me afeta, pois que me afeta pensar na palavra indiciária que se desdobra, na palavra proveniente desta inteligência do mundo, que é a inteligência de todos (as), e que de tão gigante e tão forte amedronta aqueles que se prestam a governar, sendo aprisionada, portanto, e mecanizada, portanto, e tornada menor. Já faz tempo que o nosso querido nos ensina isso; quem sabe, um dia, possamos aprender suas lições de liberdade.

Nos contos e fábulas, a expressão "era uma vez..." nos reporta ao lugar a partir do qual algo principia, gerando a expectativa de um desenvolvimento tortuoso e de um final feliz. Princípio, meio e fim - ideia boa para tratarmos de lobos maus e princesas adormecidas, mas pouco interessante para pensarmos sobre qualquer aspecto que atravesse uma vida humana. Não, esta ideia não se aplica às vidas humanas e nem tampouco à alfabetização. Esta é desprovida de inícios e finalizações, pois que se tece infinitamente em movimentos diferenciados, como um acontecimento cuja origem é parcialmente desconhecida, e o destino parcialmente ignorado. Sem confins.

\section{REFERÊNCIAS}

BRASIL. Ministério da Educação. Secretaria de Educação Fundamental. Referencial curricular nacional para a educação infantil. Brasília: MEC/SEF, 1998. v.1-3.

CERTEAU, M. de. A invenção do cotidiano. Artes de fazer. Petrópolis: Vozes, 1994. 
ESTEBAN, M. T., LOUZADA, V. Cadernos pedagógicos para a pré-escola: algumas questões sobre avaliação da aprendizagem e alfabetização para as classes populares. Revista Pedagógica, Chapecó, v. 16, n. 33, jul./dez. 2014.

FOUCAULT, M. Vigiar e punir. Petrópolis: Vozes, 1987.

FERREIRO, E. Reflexões sobre alfabetização. São Paulo: Cortez, 1995.

FREIRE, P. A importância do ato de ler. São Paulo: Cortez, 1997.

KRAMER, S., ABRAMOVAY, M. Alfabetização na pré-escola: exigência ou necessidade. Cadernos de Pesquisa, São Paulo, v. 52, fev. 1985.

LACERDA, M. P. de. A alfabetização e o inventário de uma herança. Educar em Revista, Curitiba, n. 55, p. 189-204, jan./mar. 2015. DOI: 10.1590/0104-4060.38447.

LARROSA, J. Tremores: escritos sobre experiência. Belo Horizonte: Autêntica, 2014.

MATURANA, H. Cognição, ciência e vida cotidiana. Belo Horizonte: Ed. UFMG, 2001.

SAMPAIO, C. S. Alfabetização na pré-escola. In: GARCIA, Regina Leite (Org.).

Revisitando a pré-escola. São Paulo: Cortez, 1997.

VIGOTSKI, L. S. A construção do pensamento e da linguagem. São Paulo: Martins Fontes, 2009.

VON FOERSTER, H. Visão e conhecimento: disfunções de segunda ordem. In:

SCHNITMAN, D. F. (Org.). Novos paradigmas, cultura e subjetividade. Porto Alegre: Artes Médicas, 1996.

WILLS, C D.; STEGEMAN, W. A vida no jardim de infância. São Paulo: Livraria Freitas Bastos S. A., 1967. 
Mitsi Pinheiro de Lacerda - Professora do Departamento de Ciências Humanas e do Programa de PósGraduação em Ensino da Universidade Federal Fluminense. E-mail: mitsipinheiro@id.uff.br

\section{NOTAS}

ii Base Nacional Comum Curricular em tramitação em 2017, reduz esta idade a 7 anos.

iii Neste trecho, a ênfase na negação abusa da estilística, com o uso de uma hipérbole, somente para ressaltar a crítica às políticas educacionais. É preciso registrar, contudo, a existência do trabalho de professores e pesquisadores que compreendem e atuam politicamente junto à alfabetização emancipatória e contra hegemônica.

iv $\mathrm{O}$ uso proposital do diminutivo (musiquinhas, historinha) também dispõe de apelo estilístico objetivando marcar criticamente como, por vezes, práticas que envolvem a musicalidade, corporeidade, narrativas e a ludicidade são produzidas como menores e insignificantes.

${ }^{v}$ É preciso ressaltar a importância do brincar na educação infantil, embora o artigo não se dedique a isso. Para melhor conhecimento do assunto, há excelentes trabalhos que a ele disponibilizam um tratamento o qual não é possível, a esta autora, oferecer.

${ }^{v i}$ As "Diretrizes Curriculares Nacionais para a Educação Infantil" (BRASIL, 2010) e o "Referencial Curricular Nacional para a Educação Infantil” (BRASILF, 1998) registram a relevância do brincar e da ludicidade.

vii Dentre tantos (as) pesquisadores (as) brasileiros (as) que se dedicam à alfabetização, remeto o (a) leitor (a) ao excelente trabalho da saudosa Regina Leite Garcia, e de Maria Teresa Esteban, Ana Luiza Smolka, Carmen Sanches Sampaio, Maria do Rosário Mortatti, Cláudia Gontijo e Jacqueline Morais.

viii Esta edição foi publicada a partir de cooperação entre a Agência Norte-Americana para o Desenvolvimento Internacional (USAID) e a Livraria Freitas Bastos S.A. Segundo nota da edição, trata-se de uma publicação "em prol da Aliança para o Progresso".

ix Certeau (1994) denomina como "fraco" o praticante que produz os desvios necessários à sua continuidade, instalando-se no campo do outro sem submeter-se às condições que lhe são oferecidas. Para Certeau, os fracos movem-se segundo as oportunidades que encontram ou criam: é o próprio cerceamento que favorece a que alternativas sejam criadas. Já o "forte" seria um "sujeito de querer e poder" (p. 99).

x É bastante comum encontrarmos, nas escolas, cartazes onde se encontra compilada a frase do mestre: "A leitura do mundo precede a leitura da palavra".

Submetido em: 03-12-2015 - Aceito em: 01-09-2016.

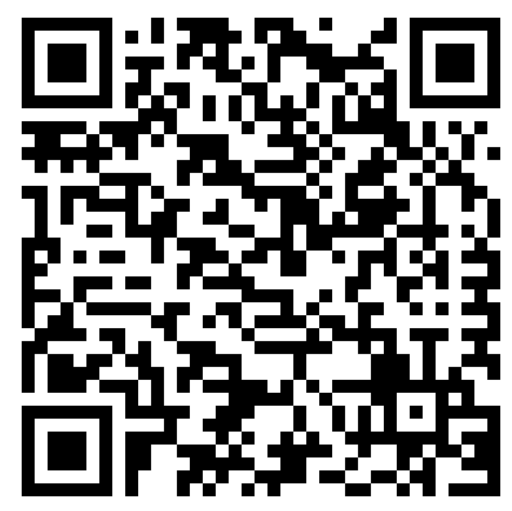

(C) Rev. Educ. Perspec.

Viçosa, $M G$

v.8

n. 1

p.20-35

jan./abr. 2017

eISSN 2178-8359 